\title{
Measuring Customer Satisfaction Level at Counter Service, SunLife Malaysia Johor Bahru
}

\section{Suraya Rosli, Beni Widarman Yus Kelana, Teo Poh Chuin}

To Link this Article: http://dx.doi.org/10.6007/IJARBSS/v11-i2/8875

DOI:10.6007/IJARBSS/v11-i2/8875

Received: 09 January 2021, Revised: 02 February 2021, Accepted: 13 February 2021

Published Online: 28 February 2021

In-Text Citation: (Rosli et al., 2021)

To Cite this Article: Rosli, S., Kelana, B. W. Y., \& Chuin, T. P. (2021). Measuring Customer Satisfaction Level at Counter Service, SunLife Malaysia Johor Bahru. International Journal of Academic Research in Business and Social Sciences, 11(2), 596-603.

Copyright: (c) 2021 The Author(s)

Published by Human Resource Management Academic Research Society (www.hrmars.com)

This article is published under the Creative Commons Attribution (CC BY 4.0) license. Anyone may reproduce, distribute, translate and create derivative works of this article (for both commercial and non-commercial purposes), subject to full attribution to the original publication and authors. The full terms of this license may be seen

at: http://creativecommons.org/licences/by/4.0/legalcode

Vol. 11, No. 2, 2021, Pg. 596 - 603

Full Terms \& Conditions of access and use can be found at http://hrmars.com/index.php/pages/detail/publication-ethics 


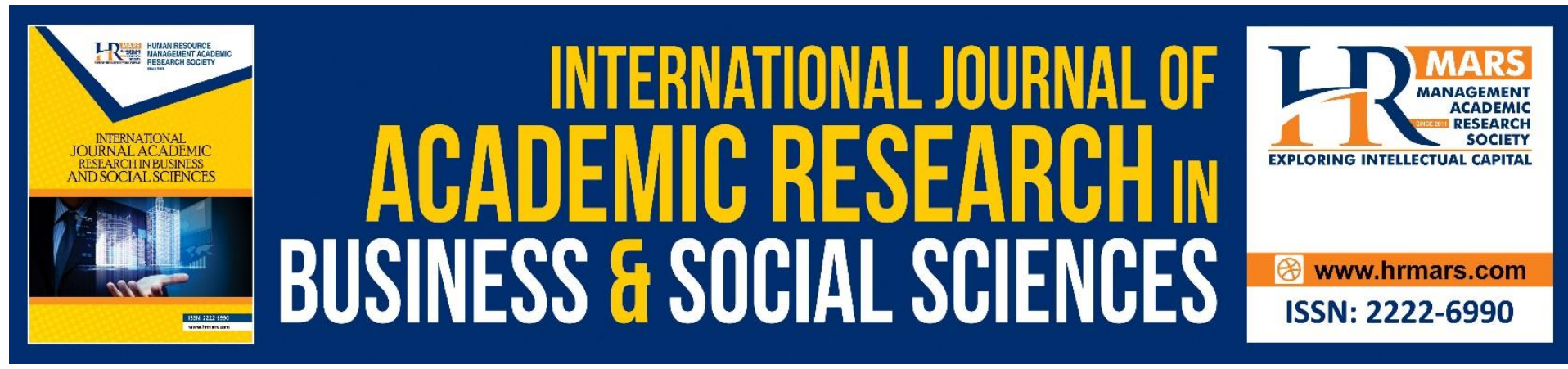

\title{
Measuring Customer Satisfaction Level at Counter Service, SunLife Malaysia Johor Bahru
}

\author{
Suraya Rosli, Beni Widarman Yus Kelana, Teo Poh Chuin \\ Azman Hashim International Business School, Universiti Teknologi Malaysia, \\ 81300, Johor Malaysia
}

Email: suraya.r@graduate.utm.my, beni@utm.my, pohchuin@utm.my

\begin{abstract}
This article was published, to identify significant effect between factors influencing customer satisfaction, in SunLife Malaysia Johor Bahru. Every business organization's success depends on the satisfaction of their customers. Service quality is well recognized to influence the customer satisfaction. According to the Life Insurance Association Malaysia (LIAM) records, there are increasing numbers of complaints were reported from 2005 until today. Some issues such as poor service, delay in settlement of claims, wrong information, price fixing and lack of professionalism in their work by the agents of insurance companies and many others reasons were reported. Although there are several studies on customer satisfaction has been carried out before, unfortunately there are not many studies were done mainly in counter service for insurance companies in Malaysia. This study aims to measure the level of factors influencing customer satisfaction towards insurance counter service. 400 numbers of participants were chosen to conduct this study consist of existing SunLife Malaysia Johor Bahru customers. Quantitative method was conducted whereby 200 sets of hard copy questionnaires were distributed to the walk-in customers in the service counter. Another 200 sets of Google Form questionnaire were distributed online. However, researcher only received back 230 sets of responded questionnaires which are sufficient number to perform the research. The result shown that there is a significant effect between the 3 construct in counter service practice towards customer satisfaction, whereby Staff has become the highest element (based on the mean score) among the three factors. This study is expected not only to prove the conceptual of counter service practice; but the empirical evidence from the study can be used in order to facilitate more detailed future studies especially in customer service fields. It is also expected to improve understandings of the factor contribute to the customer satisfaction level in the service counter. The result of this study is beneficial to the insurance sectors' counter service mainly in customer service department to enhance more customer satisfaction and loyalty towards the organizations.
\end{abstract}

Keywords: Counter Service, Customer Satisfaction, Customer Loyalty, Insurance Industry, Staff, Products, Service, Kano Model. 


\section{Introduction}

The objective of the study is to identify the significant effect between counter service practice and customer satisfaction. The study conducted based on the Noriaki Kano Satisfaction Model (1980). In this study, there are 3 variables construct that are Staff, Product and Service. This study is conducted to fill the gap, which shows that less study has been conducted for service counter in relation to customer satisfaction, especially in the life insurance sector comparing to Banks. Many firms including banking industries begin to track their customers' satisfaction through measuring their level of service quality perceived by their customers. Spreng and Olshavsky (1993) stated that customer satisfaction or dissatisfaction is considered to be the result of a comparison between the pre-use expectations that a customer has about the product or service and the post-use perception of product or service performance. In providing service quality, the role of emotion has started to come into the picture. In addition to that, Leiter and Maslach (1988) have shown that one's emotions have an influence on customer behaviour. Carlzon (1989) stated that the quality of any service encounters or "moments of truth" experienced by customers forms part of their overall impression of the whole service provided. As commented by Deming (1982), most people give their opinions based on the people that they see, and they are either satisfied or dissatisfied or delighted or even continue in between. Customer's satisfaction is a subjective and complicated phenomenon yet it directly reflects the competency of the insurance company which can be trusted by the customers. For many years, customer satisfaction has been the ultimate goal of every business organizations as it can lead to increased revenue and profit as stated by Kotler et al., (1996). Dissatisfied customers log complaint and spread the bad review of the service they received from the company. Customer complaints are mainly due to poor service, delay in settlement of claims, wrong information, price fixing and lack of professionalism in their work by the agents of insurance companies as mentioned by Ahmad and Sungip (2008). With multi-dimensional demand and challenges of globalization; organizations are forced to re-engineer their operations and systems to be more customer centric to improve the service quality to remain competitive as stated by Yasin et al., (2004); Rodie and Martin, (2001); Tan et al., (2010). Thus, to overcome the issue of customer satisfaction in service counter, the findings and discussion in this research is important to justify the significant effect between the variables. According to Rashid et al., (2004), the successful and the effective changes really depend on the main assets of the organisation which is the staff. Staffs are the factor that needs to be given more attention by the management. This is stated by Freeman (1984), individuals or groups of peoples can influence by the scope of organisation's objective that includes action, decision, guideline and company's mission. To ensure the importance of the main factor which is staff not being neglected, organisations need to consider the staff benefits and advantages so that in return, staff will give their fullest commitment to the organisation. This study is expected not only to prove the conceptual of counter service practice; but the empirical evidence from the study can be used in order to facilitate more detailed future studies especially in customer service fields. It is also expected to improve understandings of the factor contribute to the customer satisfaction level in the service counter. The result of this study is beneficial to the insurance sectors' counter service mainly in customer service department to enhance more customer satisfaction and loyalty towards the organizations. 


\section{"Linking Pin" Between Customer Satisfaction and Counter Service Practices}

Table 1 presents a brief explanation of past studies showing the relationship between Customer Satisfaction and Counter service practices to strengthen the evidence conceptually:

TABLE 1: Relationship between Customer satisfaction and Counter service practices

\begin{tabular}{|c|c|}
\hline Counter Service Practice & Remarks \\
\hline Staff & $\begin{array}{l}\text { Staffs is the first person customer will meet and interact in the } \\
\text { counter. An innovative competence is the ability to find own- } \\
\text { self in the innovative situations in terms of solving uncommon } \\
\text { problems as cited by Gajdzik (2015). What is also important is } \\
\text { the ability to think systemically, effectively operate in a } \\
\text { multicultural environment and the ability to learn or behave } \\
\text { politely among colleagues as mentioned by Jabłoński (2015). } \\
\text { As stated by Boshoff and Allen (2000), service recovery can be } \\
\text { described as the effectiveness of a staff's ability and acts in } \\
\text { resolving the service shortfall to a customer's satisfaction. } \\
\text { From Hui's ( } 2007 \text { ) point of view, service recovery is defined as } \\
\text { the attitudes of staff in handling customer problems and to } \\
\text { improve satisfaction and loyalty of customer after the } \\
\text { shortfalls of services. Hui (2007) stated that service recovery } \\
\text { involves of three attributes, namely, customer service } \\
\text { employee performance, types of employee behaviors and a } \\
\text { multidimensional construct. Knowledgeable and being } \\
\text { competence are among theories in the SERVQUAL model } \\
\text { established by Parasuraman et al. (1985), but distorted for } \\
\text { empathy and assurance in representing the behavior of } \\
\text { employee's, which decide the service quality delivered. A } \\
\text { competence staff in terms of attitude, knowledge, skills, } \\
\text { behaviour, can complete the work task given in time manner } \\
\text { and have a vast experience is the key to a customer } \\
\text { satisfaction in the service counter. }\end{array}$ \\
\hline Product & $\begin{array}{l}\text { Product quality are refer to the insurance coverage, claiming } \\
\text { process, premium payment mode, information provided in } \\
\text { the insurance policy and also the simplicity of the application } \\
\text { process. Product quality is an important factor affecting the } \\
\text { second purchase of insurance policies in Malaysia as the more } \\
\text { clearly and specific details given by the agent of the insurance } \\
\text { company as stated in their policies, the less likely will be the } \\
\text { information wrongly delivered to the customer. Srivastava } \\
\text { (2013) pointed out that if customer's expectations on quality } \\
\text { of product and services provided are met through a certain } \\
\text { insurance agent, it will affect their purchasing decision } \\
\text { positively. Brody, Highfield, Wilson, Lindell, \& Blessing (2017) } \\
\text { stated that the customer will tend to buy insurance when they } \\
\text { are in the risk situation. The information searching could } \\
\text { provide better understanding about the insurance policy }\end{array}$ \\
\hline
\end{tabular}




\begin{tabular}{l|l}
\hline Service & $\begin{array}{l}\text { before customer purchase the insurance as mentioned by Lin, } \\
\text { \& Chen (2006). Insurance companies may improve their } \\
\text { product quality for example improve and increase more } \\
\text { innovative new insurance products which are suitable to the } \\
\text { society of today as cited by Chong (2017). }\end{array}$ \\
\hline $\begin{array}{l}\text { In 2003, the whole service quality is signified by human skill, } \\
\text { empathy variables and tangible as mentioned by Jabnoun and } \\
\text { Hassan Al-Tamimi (2003). Anyhow, the idea of service quality } \\
\text { has been extended to customer focus, convenience, employee } \\
\text { service, service architecture and empathy as confirmed by } \\
\text { Muhammad Awan et al. (2011). Internet or online website } \\
\text { portal is another new service platform for customers in } \\
\text { accessing to the organization customer service. Previous } \\
\text { researcher stated that online service quality is constructed } \\
\text { with the website interactivity, ease of use, assurance, } \\
\text { customization the customers' want and reaction as cited by } \\
\text { Butt and Aftab (2013). Malaysians prefer to buy life insurance } \\
\text { from agents they believe are trustworthy after having } \\
\text { established a long-term relationship with them, and when } \\
\text { they are assured that the agents are able to deliver } \\
\text { satisfactory services. As stated by Lee and Noriza (2018), they } \\
\text { found that the key aspects influencing Malaysia population in } \\
\text { buying insurance is because of the service provided by certain } \\
\text { insurance companies. When customer received good and } \\
\text { professional services, they will be satisfied and happy, and } \\
\text { definitely will recommend other peoples for the services. }\end{array}$ \\
\hline
\end{tabular}

\section{Method}

This research is conducted on May 2020 using survey method to existing SunLife Malaysia Johor Bahru customers. The aspects examined in this research include service quality toward customer satisfaction and loyalty. This research will be conducted by distributing the questionnaire via hard copy and also by using social media platform which is Google Form. According to Krejie and Morgan (1970), the total sample responden need to have in this research based on the calculation sample method is 383 respondents. "Systematic random sampling" technique was used in the study involving a sample of 400 respondents, however, the sample was left with just as many as 230 customers responded to the questionnaires which are sufficient number to perform the research and it fulfilled the requirement. The data is analyzed by a multiple regression statistic and SEM. SEM analysis or Structural Equation Modeling is one of the testing techniques used in the study to answer the research objectives. This technique is suitable for testing the causal relationship between the variables involved in the study of quantitative research. The collected data is measured by Likert scale with one to five scales. The result of analysis is then interpreted and finally, conclusion and recommendations are made.

\section{Result and Discussion}

This research analysis has been carried out based on the data collected, in order to achieve the objectives of this research. Descriptive analysis has been done by using SPSS 
version 23.0, that providing analysis upon the respondent demographic data. The first research objective, which is to find the independent variables with the highest level has been determined by using mean score value. The result show that Staff recorded the highest mean score value among the respondent meanwhile Product recorded the lowest value. The second research objective is to identify significant effect (value $P \leq 0.05$ ) between factors influencing customer satisfaction in SunLife Malaysia Johor Bahru. Based on Figure 1, SEM analysis results show all 3 counter service practices which are Staff, Product and Service have significant effect towards customer satisfaction level, thus hypothesis $\mathrm{H} 1, \mathrm{H} 2$ and $\mathrm{H} 3$ are accepted. Meanwhile, the total value of variance contributed by all the three practice of customer satisfaction level is 0.77 @ 77 percent. This shows that counter service practices involved have crucial impact on customer satisfaction level and has contributed empirical evidence to the development of ideas and models led by Noriaki Kano (1980).

Besides that, researcher also prove that the Staff factor is the most dominant that supported the research model. This is due to staff being the significant element and most important asset in the organisation that can contribute to the organisation's advantage in the long run. Not only staff, other elements such as service and product are also seen to give impact to the organisation advantages in the long run.

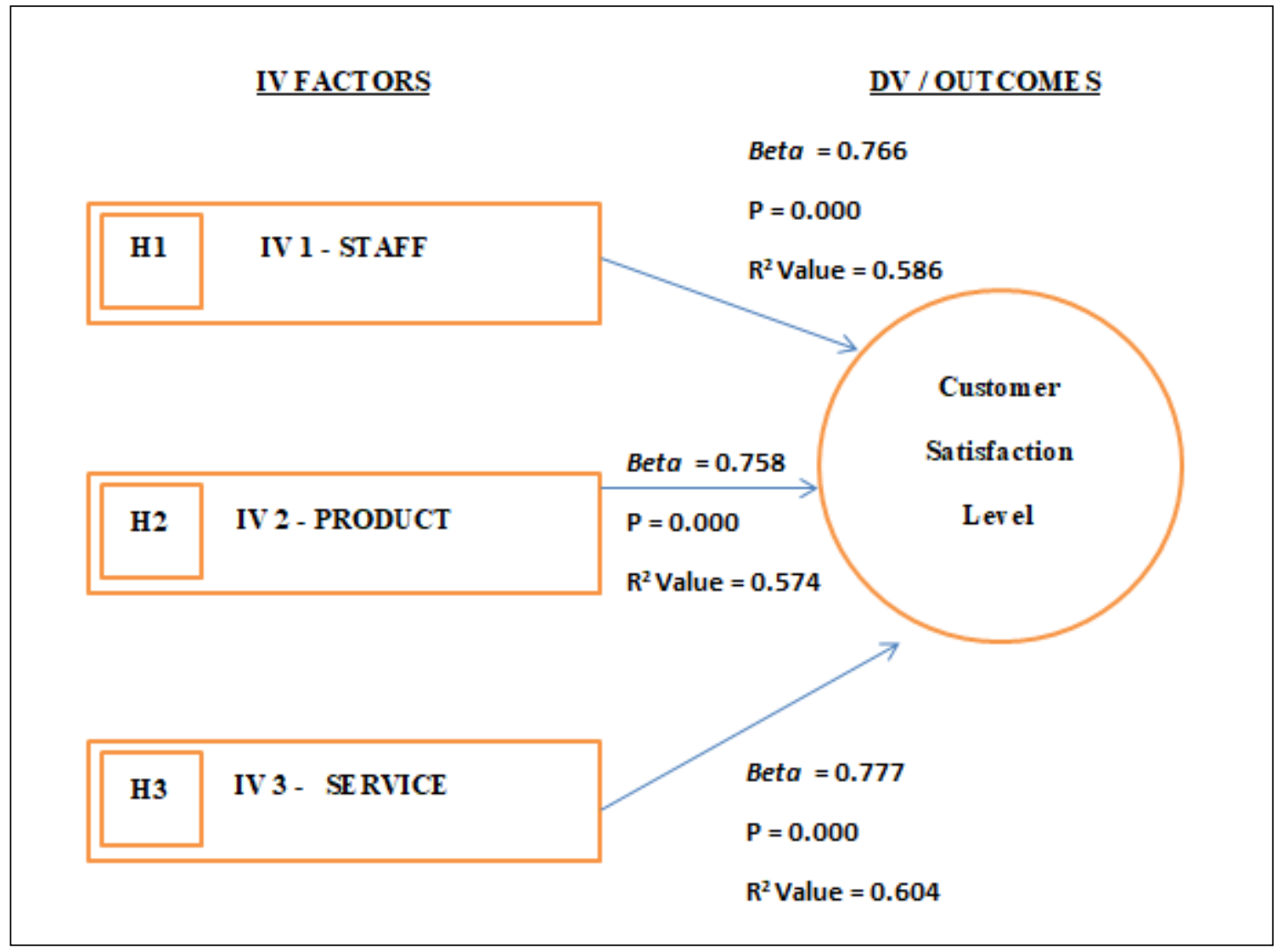

Figure 1: Result of SEM analysis (Significant effects of counter service practices on customer satisfaction level in insurance industries in Malaysia)

\section{Conclusion}

In conclusion, conceptual and empirical evidences found in the study have proven that the Noriaki Kano Model (1980) is able to improve customer satisfaction level especially in the scope of study, namely in life insurance industries in Malaysia. Next, these findings have opened up opportunities for future researchers to enhance their understanding by examining 
new factors that could contribute to the improvement of customer satisfaction level in greater depth. Through the analysis finding, it shows that measurement of customer satisfaction level had already been implemented in many organizations in Malaysia. However, the effectiveness needs to be improve so that it can overcome the unnecessary dissatisfaction issues or complaints in the future.

\section{Contribution}

Theoretically, this study has contributed in measuring customer satisfaction level in counter service by using the Noriaki Kano Model (1980), whereby previous researchers also have often using the theory. The finding from the research shows that customer service practice in the model can increase customer satisfaction especially in the scope of research involving staff, product and service rendered in counter whether it is directly or indirectly. From the finding, researcher can identify the weakness and strength that can be added in improvising the counter service practice not only in SunLife Malaysia Johor Bahru but also in other organisations. The staff, management team, life insurance association and Bank Negara need to take proactive steps in increasing customers satisfaction level and maintaining customers loyalty towards the organization. In conclusion, SunLife Malaysia needs to ensure their main assets which is staff always be in the high productive level, knowledgeable and competence so that it can make the organisation more competitive and become one of the preferred life insurance companies that sustain in the market.

\section{Acknowledgments}

This research has been supported by Universiti Teknologi Malaysia (UTM). The author would like to thanks to Dr. Beni Widarman Yus Kelana and Dr. Teo Poh Chuin for infinite support in the planning, implementation and success of this research. Gratitude also goes to the author's family and friends for their understanding in supporting the completion of this research.

\section{References}

Awan, H. M., Bukhari, K. S., \& Iqbal, A. (2011). Service quality and customer satisfaction in the banking sector. Journal of Islamic Marketing.

Babakus, E., Cravens, D. W., Johnston, M., \& Moncrief, W. C. (1999). The role of emotional exhaustion in sales force attitude and behavior relationships. Journal of the Academy of Marketing Science, 27(1), 58-70.

Boshoff, C., \& Allen, J. (2000). The influence of selected antecedents on frontline staff's perceptions of service recovery performance. International Journal of Service Industry Management.

Brody, S. D., Highfield, W. E., Wilson, M., Lindell, M. K., \& Blessing, R. (2017). Understanding the motivations of coastal residents to voluntarily purchase federal flood insurance. Journal of Risk Research, 20(6), 760-775.

Butt, M. M., \& Aftab, M. (2013). Incorporating attitude towards Halal banking in an integrated service quality, satisfaction, trust and loyalty model in online Islamic banking context. International Journal of Bank Marketing.

Chong, W. J., Eng, E. A., Ong, J. J., Ngu, J. Y., \& Soon, Y. M. (2017). What Drive the Second Purchase of Malaysia Insurance Consumers (Doctoral dissertation, UTAR).

Douglas, J., Douglas, A., \& Barnes, B. (2006). Measuring student satisfaction at a UK university. Quality 
assurance in education.

Freeman, R. E., \& Phillips, R. A. (2002). Stakeholder theory: A libertarian defense. Business ethics quarterly, 12(3), 331-349.

Hair, J. F., Black, W. C., \& Babin, A. (2010). RE and Tatham, RL (2006), Multivariate Data Analysis.

Jabnoun, N., \& Al-Tamimi, H. A. H. (2003). Measuring perceived service quality at UAE commercial banks. International Journal of Quality \& Reliability Management.

Kochmańska, A., \& Tokar, J. (2019). The development centre method as a tool for assessing the competences of the management staff. Zeszyty Naukowe. Organizacja i Zarządzanie/Politechnika Śląska

Krejcie, R. V., \& Morgan, D. W. (1970). Determining sample size for research activities. Educational and psychological measurement, 30(3), 607-610.

Kumar, M., Kee, F. T., \& Manshor, A. T. (2009). Determining the relative importance of critical factors in delivering service quality of banks. Managing Service Quality: An International Journal.

Liao, H. (2007). Do it right this time: The role of employee service recovery performance in customer-

perceived justice and customer loyalty after service failures. Journal of applied psychology, 92(2), 475.

Lin, L. Y., \& Chen, C. S. (2006). The influence of the country-of-origin image, product knowledge and product involvement on consumer purchase decisions: an empirical study of insurance and catering services in Taiwan. Journal of consumer marketing.

Ooi, K. B., Lin, B., Tan, B. I., \& Chong, A. Y. L. (2011). Are TQM practices supporting customer satisfaction and service quality?. Journal of Services Marketing.

Parasuraman, A., Zeithaml, V. A., \& Berry, L. L. (1985). A conceptual model of service quality and its implications for future research. Journal of marketing, 49(4), 41-50.

Piaralal, S. K., Bhatti, M. A., Piaralal, N. K., \& Juhari, A. S. (2016). Factors affecting service recovery performance and customer service employees. International Journal of Productivity and Performance Management.

Rambeli, N. B., Ramli, E. B. H., Mahdinezhad, M., Jalil, N. B. A., Hashim, A., \& Bakri, S. B. M. (2018). Issues in Insurance Expenses among the Lowest Income Households in Malaysia: Validity and Reliability Analyses. International Journal of Academic Research in Business and Social Sciences, 8(10).

Sit, W. Y., Ooi, K. B., Lin, B., \& Chong, A. Y. L. (2009). TQM and customer satisfaction in Malaysia's service sector. Industrial Management \& Data Systems.

Srivastava, M., \& Rai, A. K. (2013). Investigating the mediating effect of customer satisfaction in the service quality-customer loyalty relationship. Journal of Consumer Satisfaction, Dissatisfaction \& Complaining Behavior, 26(3), 95-109.

Xu, Q., Jiao, R. J., Yang, X., Helander, M., Khalid, H. M., \& Opperud, A. (2009). An analytical Kano model for customer need analysis. Design studies, 30(1), 87-110.

Yunus, N. S. N. M., Bojei, J., \& Rashid, W. E. W. (2013). Service Quality towards Customer Loyalty in Malaysia's Domestic Low Cost Airline Services. International Journal of eEducation, e-Business, e-Management and e-Learning, 3(4), 333. 